\title{
Catalyst Properties and Catalytic Performance of Char from Biomass Gasification
}

\author{
Naomi B. Klinghoffer, ${ }^{\dagger}$ Marco J. Castaldi, ${ }^{\dagger *}$ and Ange Nzihou ${ }^{\ddagger}$ \\ ${ }^{\dagger}$ Columbia University, Department of Earth and Environmental Engineering, New York 10027, United States \\ "Université de Toulouse, Mines Albi, CNRS, Centre RAPSODEE, Campus Jarlard, F-81013 Albi Cedex 09, France
}

\begin{abstract}
Gasification provides a mechanism to convert solids, such as biomass, coal, or waste, into fuels that can be easily integrated into current infrastructure. This paper discusses the use of residual char from a biomass gasifier as a catalyst for tar decomposition and presents an investigation of the catalytic properties of the char. Poplar wood was gasified in a fluidized bed reactor at temperatures ranging from 550 to $920{ }^{\circ} \mathrm{C}$ in reaction environments of $90 \%$ steam $/ 10 \% \mathrm{~N}_{2}$ and $90 \% \mathrm{~N}_{2} / 10 \% \mathrm{CO}_{2}$. The properties of the char recovered from the process were analyzed, and the catalytic performance for hydrocarbon cracking reactions was tested. Brunauer-Emmett-Teller (BET) measurements showed that the surface area of the char was higher than conventional catalyst carriers. The surface area, which ranged from 429 to $687 \mathrm{~m}^{2} \mathrm{~g}^{-1}$, increased with temperature and reaction time. The catalytic activity of the char was demonstrated through testing the catalytic decomposition of methane and propane to produce $\mathrm{H}_{2}$ and solid carbon. Higher char surface area resulted in increased performance, but pore size distribution also affected the activity of the catalyst, and evidence of diffusion limitations in microporous char was observed. Clusters of iron were present on the surface of the char. After being used for catalytic applications, carbon deposition was observed on the iron cluster and on the pores of the char, indicating that these sites may influence the reaction. When the char was heated to $800{ }^{\circ} \mathrm{C}$ in an inert $\left(\mathrm{N}_{2}\right)$, atmosphere mass loss was observed, which varied based on the type of char and the time. ESEM/EDX showed that when char was heated to $1000{ }^{\circ} \mathrm{C}$ under $\mathrm{N}_{2}$, oxygen and metals migrated to the surface of the char, which may impact its catalytic activity. Through investigating the properties and performance of biomass gasification char, this paper demonstrates its potential to replace expensive tar decomposition catalysts with char catalysts, which are continuously produced on-site in the gasification process.
\end{abstract}

\section{INTRODUCTION}

Biomass has the potential for meeting a significant portion of the demand for energy and transportation fuels in the near future. Gasification is a method for converting biomass into synthesis gas, and it has been gaining increasing attention in recent years. This process involves partial oxidation of a solid feedstock, such as biomass or waste, with a coreactant (e.g., air, $\mathrm{CO}_{2}$, or steam) in order to generate synthesis gas, which is a mixture of $\mathrm{CO}$ and $\mathrm{H}_{2}$. This can be combusted in a gas turbine or fuel cell to generate power and heat or can be used to make fuels and chemicals via Fischer-Tropsch (F-T) synthesis. Synthesis gas can also be used to make methanol, dimethylether (DME), or synthetic natural gas (SNG). Gasification produces three main components: gas, tar, and solid residue (classified as ash or char, depending on its carbon content). The gas, which consists primarily of $\mathrm{H}_{2}, \mathrm{CO}, \mathrm{CO}_{2}$, and other small hydrocarbons, is the desired product that is used for fuels synthesis or direct electricity or heat production. Tars are liquid organic hydrocarbons that are primarily aromatic compounds. They are formed from solid fuel that has not been fully decomposed to gas phase products. Ash consists of the minerals or metals that are inherently present in the raw material and are not converted to gas or liquid phase products. Char is a residue that is primarily composed of solid unreacted carbon and also contains ash. Char may be burned for energy recovery or directly disposed of in a landfill, similar to ash disposal. Currently, there are limited uses for ash or char from gasification systems, aside from use in construction applications or as alternate daily cover for landfills. ${ }^{1}$ There is active research in the area of soil amendment use, but this has yet to be deployed on a large scale. $^{2}$

This paper investigates the catalytic properties and performance of char from biomass gasification. While the objective of gasification is to achieve high conversion of carbon to gas phase products, gasifiers typically produce a solid residue that is rich in carbon. For example, a pilot plant that gasified wood sawdust and sunflower seeds pellets with air reported that the carbon content of the solid residue was $>80 \%$. Temperatures in that reactor were measured to be as high as $1109^{\circ} \mathrm{C} .{ }^{3}$ Therefore, it is relevant to investigate uses for char that is recovered from gasifiers. Ash, which is present in char, contains metals that are used in catalytic applications. Generally, catalysts are supported on high surface area materials such as alumina, zirconia, ceria, or carbon through an impregnation process. Char from gasification provides a high surface area support for the ash, which is already impregnated in the char, thereby producing a supported metal catalyst. However, the location and dispersion of the metals, as well as their activity in this state needs to be determined. The surface area of char is similar to or greater than that of common catalyst carriers. For example, typical catalyst carriers have surface areas ranging from $50-400 \mathrm{~m}^{2} \mathrm{~g}^{-1}$, 
depending on the type of carrier. The surface area of char was reported to range from 429 to $687 \mathrm{~m}^{2} \mathrm{~g}^{-1,4}$ which is beneficial because catalysts should have high surface area in order to increase the availability of catalytic sites. The composition of the char will vary depending on the solid fuel source and the gasification process conditions. However, biomass typically contains metals such as iron, copper, and calcium, which are often used as catalysts or promoters. Previous work has shown that the surface area of the char and char yield (which is defined as the fraction of the initial mass that ends up as char) will vary depending on gasification conditions. ${ }^{4}$

Carbon has been widely used in catalytic applications such as oxidative dehydrogenation of ethylbenzene, dehydration of alcohols, $\mathrm{SO}_{x}$ oxidation, $\mathrm{NO}_{x}$ reduction, and ozonation of pollutants. ${ }^{5}$ In addition, carbon catalyzed $\mathrm{H}_{2}$ production from methane has received growing interest over the past decade. ${ }^{6-8}$ In many of these cases, the carbon is activated in order to create specific surface properties and surface area. The research presented in this paper focuses on the use of residual char from gasification processes where char properties are determined by the gasification conditions. Therefore, the process of creating catalytically active char is constrained by the need to achieve desired gasification products. The presence of metals on a carbon support, which is observed in char, may prove to be beneficial for catalytic applications. As an example, Ma et al. used activated carbon as a support for a Fischer-Tropsch catalyst ( $\mathrm{Fe}$, with $\mathrm{Mo}-\mathrm{Cu}-\mathrm{K}$ additives), obtained uniform dispersion over the support, and demonstrated activity of the carbon-supported catalysts. ${ }^{9}$ Other research has shown that there may be positive interactions between metal and carbon support materials. ${ }^{10-12}$

This research investigates the catalytic properties of char for its use in catalyzing decomposition of tars. These compounds must be removed from synthesis gas because tars can condense in downstream equipment or crack, which may result in deposition of solid carbon where it is not desired. ${ }^{13,14}$ Tars can be destroyed catalytically or thermally, with thermal decomposition requiring higher temperatures than catalytic reforming. Thermal tar cracking has been reported at temperatures ranging from 700 to $1250{ }^{\circ} \mathrm{C}$, although operating in the lower regime of this temperature range will not result in complete conversion of tars. ${ }^{15}$ Catalytic conversion has been reported in the temperature range $550-900{ }^{\circ} \mathrm{C} .{ }^{15}$ Catalysts are typically composed of minerals such as olivine or dolomite or base metals such as nickel. One of the main concerns with this process is catalyst deactivation. The most common methods of deactivation are coking, attrition, or sulfur poisoning. ${ }^{16}$ Coking is particularly prevalent with nickel catalysts. ${ }^{17}$ To reduce coking, others have looked at combining nickel with other alkali or alkaline earth metals. For example, using a guard bed of calcined dolomite or addition of magnesium to the nickel catalyst has been shown to reduce coke formation. ${ }^{17,18}$ Using catalysts such as dolomite and olivine without the addition of base metals is less effective for conversion of tars than using metal catalysts. El-Rub et al. report that nickel based catalysts are 8-10 times more active than dolomite. ${ }^{14}$ Catalytic destruction of tars can be done in a secondary catalytic reactor or by introducing the catalyst into the gasifier (premixed with the solid fuel). ${ }^{19,20}$ However, both premixing catalysts and placing them in a secondary reactor present a problem of catalyst recovery. The challenge of catalyst recovery and the rapid catalyst deactivation during tar decomposition necessitates use of a catalyst that is inexpensive and easily replaceable, such as char or ash.
Literature findings have shown that char from gasification processes can catalyze tar decomposition. ${ }^{21-24}$ In addition to providing a cheap and replaceable catalyst, the use of char is beneficial with respect to overall system efficiency. When char is thermally treated, it decomposes further, thus releasing more of the carbon from the original fuel into the gas phase while simultaneously converting tars to useful products. El-Rub et al. demonstrated that char can catalyze the decomposition of tars. They were able to decompose naphthalene, a tar surrogate, using biomass char and found that the char had higher activity than ash. ${ }^{22}$ This suggests that the metal-carbon interactions may play a role during catalytic reforming of tars. The role of metal-carbon interactions in reforming of tars was also discussed by Min et al., who used char supported catalysts for tar reforming. ${ }^{24}$ Wang et al. showed that char can be an effective catalyst support for synthesis gas cleanup. Using benzene as a tar surrogate, they achieved $30 \%$ conversion with char at $900{ }^{\circ} \mathrm{C}$. After mixing $\mathrm{NiO}$ with char at a nickel loadings of $20 \mathrm{wt} \%$, over $80 \%$ benzene removal was achieved at the same temperature. ${ }^{23}$ While these recent papers have shown that char or char supported catalysts have the ability to decompose tar, there is limited information on the properties that afford this activity. An understanding of such properties will enable the selection of specific gasification conditions in order to generate highly active char.

Char has some similar properties to activated carbon (AC), since it is prepared in a similar way, by exposure to steam or $\mathrm{CO}_{2}$ at elevated temperatures. The properties that impact the catalytic performance of AC catalysts are textural properties, such as surface area and pore size, and surface properties, such as oxygen and nitrogen functionalities. ${ }^{5}$ Some have reported surface properties to have a more significant impact on catalyst performance, while it has also been found that surface properties and textural properties are not independent. AC is used in many catalytic applications and for adsorption of compounds such as aromatics. ${ }^{5}$ The impact of AC properties on adsorption of aromatics has been studied and can be used to help in understanding the properties in char that will improve its performance in the catalytic conversion of aromatics. A char catalyst must be able to adsorb aromatics and subsequently release the products after the reaction has taken place. Franz et al. found that while increasing surface oxygen decreases adsorption of aromatics, surface oxygen has an important role in attracting water molecules. ${ }^{25}$ This is undesirable in the case of using AC for adsorption of aromatics, especially since it can lead to pore blockage. However, if char is used to catalyze steam reforming of tar, adsorption of water may be desirable, since water is a reactant.

\section{EXPERIMENTAL SECTION}

All gasification experiments presented in this paper were done with poplar wood. While ultimately gasification would apply to mixed waste, experiments were done with wood because a homogeneous starting material would allow for better comparison of chars generated under different gasification conditions.

2.1. Gasification Experiments. Fluidized Bed Reactor. Char was generated in a fluidized bed reactor. The reactor was charged with a set amount of poplar wood, closed, and then gases were introduced at controlled flow rates of 400 SLPM $\mathrm{kg}^{-1}$ biomass. The stainless steel reactor was $23.6 \mathrm{in}$. high and 2.4 in. internal diameter. It was equipped with a frit on the bottom to hold the biomass, and 10 thermocouples were placed 
throughout the reactor in the vertical direction to measure the temperature profile. A thermocouple placed close to the middle of the reactor was connected to a Eurotherm temperature controller. A frit was secured on top of the reactor to ensure that all char remained in the reactor for collection. The system was heated at $20{ }^{\circ} \mathrm{C} \mathrm{min}^{-1}$ to a predetermined maximum temperature where it was held for $30 \mathrm{~min}$ or $1 \mathrm{~h}$. Experiments were done in $10 \% \mathrm{CO}_{2}$ and $90 \% \mathrm{~N}_{2}$ at the following conditions: (i) $550{ }^{\circ} \mathrm{C}$ for $30 \mathrm{~min}$, (ii) $750{ }^{\circ} \mathrm{C}$ for $30 \mathrm{~min}$, (iii) $920{ }^{\circ} \mathrm{C}$ for $30 \mathrm{~min}$. Gasification was also done in $90 \% \mathrm{H}_{2} \mathrm{O}$ and $10 \% \mathrm{~N}_{2}$ at the following conditions: (i) $550{ }^{\circ} \mathrm{C}$ for $30 \mathrm{~min}$, (ii) $750{ }^{\circ} \mathrm{C}$ for $30 \mathrm{~min}$, (iii) $750{ }^{\circ} \mathrm{C}$ for $1 \mathrm{~h}$. After each experiment, the char was collected and weighed.

Environmental Scanning Electron Microscope (ESEM). Gasification experiments were done in an FEI XL30 environmental scanning electron microscope under air, steam, and $\mathrm{CO}_{2}$. A piece of poplar wood was placed inside the ESEM and was heated under each gas to 1000 at $20{ }^{\circ} \mathrm{C} \min ^{-1}$. The pressure was typically between 93 and $187 \mathrm{~Pa}$ (0.7-1.4 Torr). Images were taken throughout the gasification process to observe the physical changes in the structure.

2.2. Char Characterization. The Brunauer-EmmettTeller (BET) surface area of the char was measured with a Micromeritics, Gemini instrument. The physical structure and chemical composition was analyzed in an FEI XL30 ESEM with energy dispersive X-ray spectrometry (ESEM/EDX).

2.3. Catalytic Activity Testing. The catalytic activity of the char was tested by using it to catalyze hydrocarbon cracking reactions. Methane and propane were chosen in order to limit the chemical species resulting from the reaction. This test indicates if the char has the potential to catalyze more complex reactions and allows for comparison of the performance of different char samples. The experiments were done by placing the char in a Netzsch STA 449 F3 thermogravimetric analyzer TGA) and introducing a hydrocarbon gas while heating at $5 \mathrm{~K}$ $\min ^{-1}$ to $900{ }^{\circ} \mathrm{C}$. The mass gain measured by the TGA and the gas phase components that were measured in an Agilent 3000A micro-gas chromatograph were used to determine the extent of reaction. Mass gain represents reaction extent since these reactions produce carbon on the surface of the char, which is easily measured with a TGA. Measurement of gas phase products confirmed that the cracking reactions were taking place, for example by observing production of $\mathrm{H}_{2}$. The microgas chromatograph had a molecular sieve 5A column and a Plot $\mathrm{U}$ column coupled with a thermal conductivity detector (TCD). Char activity testing was also done in a Netzsch STA 409PC Luxx TGA. All mass gain results presented in this paper are the net mass gain once the background effect (the same reaction conditions with no char) was subtracted.

\section{RESULTS AND DISCUSSION}

3.1. Char Properties. Char was recovered from poplar wood gasification in a fluidized bed reactor under $\mathrm{CO}_{2}$ or steam at temperatures ranging from 550 to $920{ }^{\circ} \mathrm{C}$. The char properties were analyzed and reported in detail in a previous publication. ${ }^{4}$ Some of these results are summarized in this section, as they will be referred to in this paper. The BET surface area of the char samples is shown in Table 1. The char samples obtained from gasification at $550{ }^{\circ} \mathrm{C}$ did not yield acceptable quality BET measurements due to a high concentration of residual organics, thus are not reported. The remaining samples produced good quality measurements. Two trends were observed: longer reaction time or higher
Table 1. Summary of BET Surface Area and Char Yield from Gasification of Poplar Wood in a Fluidized Bed

$\begin{array}{ccccc}\text { sample name } & \begin{array}{c}\text { gasification } \\ \text { atmosphere }\end{array} & \begin{array}{c}\text { temp.; } \\ \text { time at } \\ \text { temp. }\end{array} & \begin{array}{c}\text { BET } \\ \text { surface } \\ \text { area } \\ \left(\mathrm{m}^{2} \mathrm{~g}^{-1}\right)\end{array} & \begin{array}{c}\text { char } \\ \text { recovered (\% } \\ \text { of initial } \\ \text { mass })\end{array} \\ \mathrm{H}_{2} \mathrm{O}-550-30 & 90 \% \mathrm{H}_{2} \mathrm{O} / 10 \% \mathrm{~N}_{2} & \begin{array}{c}550{ }^{\circ} \mathrm{C} \text {; } \\ 30 \mathrm{~min}\end{array} & a & 14.1 \\ \mathrm{H}_{2} \mathrm{O}-750-30 & 90 \% \mathrm{H}_{2} \mathrm{O} / 10 \% \mathrm{~N}_{2} & \begin{array}{c}750{ }^{\circ} \mathrm{C} ; \\ 30 \mathrm{~min}\end{array} & 429 & 5.60 \\ \mathrm{H}_{2} \mathrm{O}-750-60 & 90 \% \mathrm{H}_{2} \mathrm{O} / 10 \% \mathrm{~N}_{2} & \begin{array}{c}750{ }^{\circ} \mathrm{C} ; \\ 60 \mathrm{~min}\end{array} & 621 & 4.95 \\ \mathrm{CO}_{2}-550-30 & 10 \% \mathrm{CO}_{2} / 90 \% \mathrm{~N}_{2} & \begin{array}{c}550{ }^{\circ} \mathrm{C} ; \\ 30 \mathrm{~min}\end{array} & a & 16.2 \\ \mathrm{CO}_{2}-750-30 & 10 \% \mathrm{CO}_{2} / 90 \% \mathrm{~N}_{2} & \begin{array}{c}750{ }^{\circ} \mathrm{C} ; \\ 30 \mathrm{~min}\end{array} & 435 & 15.4 \\ \mathrm{CO}_{2}-920-30 & 10 \% \mathrm{CO}_{2} / 90 \% \mathrm{~N}_{2} & \begin{array}{c}920^{\circ} \mathrm{C} ; \\ 30 \mathrm{~min}\end{array} & 687 & 11.8\end{array}$

${ }^{a} \mathrm{BET}$ measurements did not yield acceptable quality results. This is likely due to residual organics in the biomass which were difficult to fully evacuate from the samples.

temperatures created a higher surface area char. Pore size distribution was measured for some of the samples. The effect of the coreactant on pore size was analyzed by comparing the sample $\mathrm{CO}_{2}-750-30$ to $\mathrm{H}_{2} \mathrm{O}-750-30$. The cumulative pore volume for pores smaller than $0.8 \mathrm{~nm}$ was $0.18 \mathrm{~cm}^{3} \mathrm{~g}^{-1}$ for sample $\mathrm{CO}_{2}-750-30$. The pore volume in this range was measured to be 0.0 for sample $\mathrm{H}_{2} \mathrm{O}-750-30$. This shows that $\mathrm{CO}_{2}$ gasification creates and maintains a micropore network, whereas steam gasification does not. The effect of temperature on micropore volume is understood by comparing the samples $\mathrm{CO}_{2}-750-30$ and $\mathrm{CO}_{2}-920-30 . \mathrm{CO}_{2}-920-30$ had a cumulative pore volume for pores smaller than $0.8 \mathrm{~nm}$ of $0.30 \mathrm{~cm}^{3} \mathrm{~g}^{-1}$, which is greater than the $0.18 \mathrm{~cm}^{3} \mathrm{~g}^{-1}$ measured for $\mathrm{CO}_{2}-750$ 30. Therefore, higher temperatures result in higher total micropore volume. The fact that micropores were observed for $\mathrm{CO}_{2}$ gasification but not for steam gasification suggests that either micropores are not formed during gasification with steam, or that sintering takes place, which eliminates the micropores that may have formed or been present in the raw material. This will be discussed further later in this section, with the support of ESEM data. Table 1 shows the char production for samples $\mathrm{H}_{2} \mathrm{O}-750-30$ and $\mathrm{H}_{2} \mathrm{O}-750-60$, where the only difference between the two tests is the time spent at $750{ }^{\circ} \mathrm{C}(30$ min versus $60 \mathrm{~min}$ ). Mass loss was similar for the two samples, but the surface area was much higher when gasification time increased $\left(429 \mathrm{~m}^{2} \mathrm{~g}^{-1}\right.$ for $\mathrm{H}_{2} \mathrm{O}-750-30$ and $621 \mathrm{~m}^{2} \mathrm{~g}^{-1}$ for $\left.\mathrm{H}_{2} \mathrm{O}-750-60\right)$. In other words, the char surface area increased, while the overall production of gas/liquid products did not change. When process conditions are modified in order to achieve desirable char properties (for example, high surface area), it is important to consider the impacts on overall gas recovery, since syngas production is the primary purpose of gasification. In this case, there is flexibility in process design where char properties can be modified without impacting product recovery.

The poplar wood was also gasified in an ESEM. This instrument enabled the sample to be heated and observed on a micrometer scale throughout the reaction. The ESEM operates at higher pressures than a conventional SEM and allows for a coreactant to be introduced into the sample chamber throughout the experiment. The poplar was heated at $20{ }^{\circ} \mathrm{C}$ $\min ^{-1}$ to $1000{ }^{\circ} \mathrm{C}$ under $\mathrm{CO}_{2}, \mathrm{H}_{2} \mathrm{O}$, or air, and images taken throughout gasification are shown in Figure 1. The goal of this 

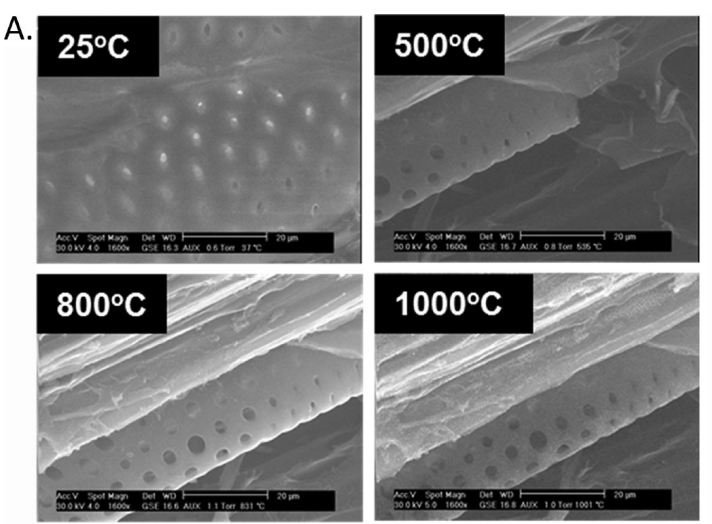

$\mathrm{CO}_{2}$ gasification: pores expand at low temperature and are maintained
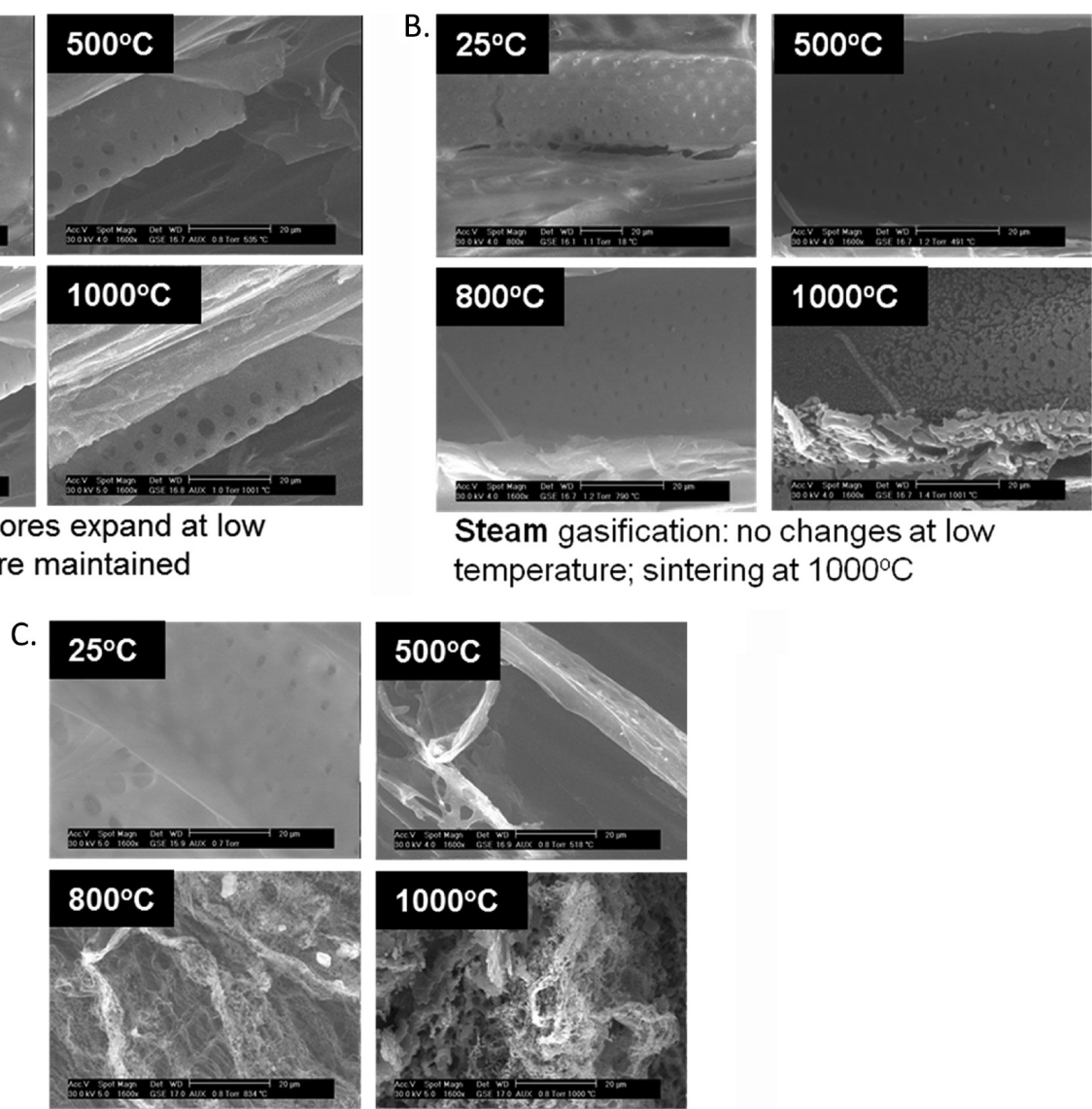

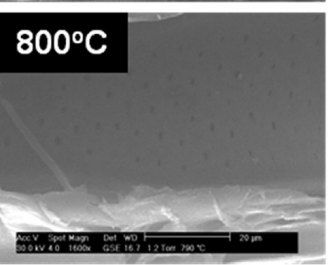

Steam gasification: no changes at low temperature; sintering at $1000^{\circ} \mathrm{C}$
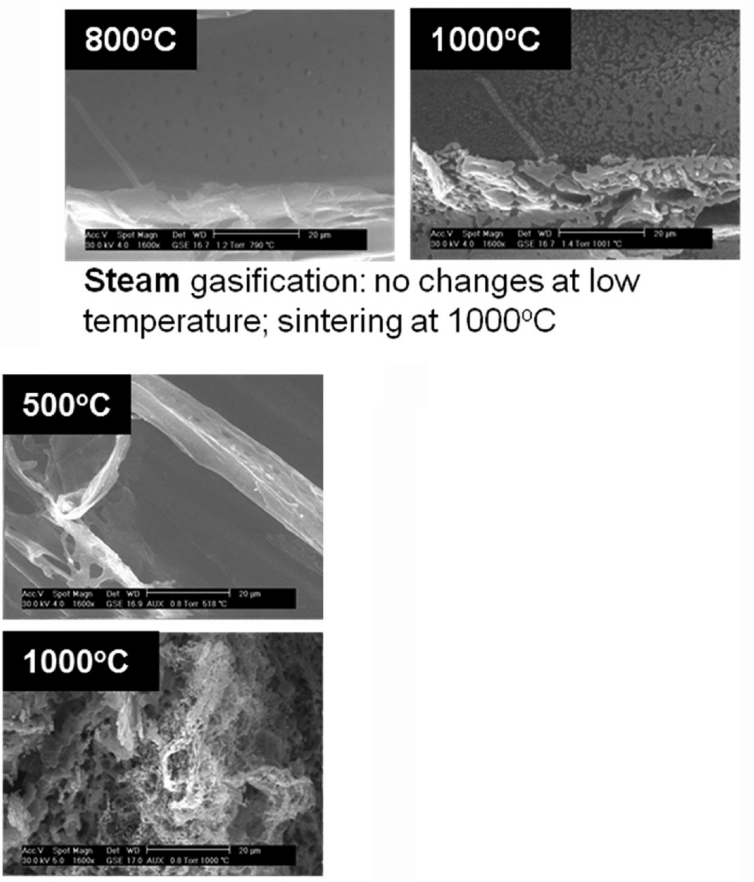

Air gasification: structure decomposes

rapidly, beginning at low temperatures

Figure 1. Gasification of poplar wood in an ESEM under (A) $\mathrm{CO}_{2}$, (B) steam, and (C) air. Porosity is highly dependent on coreactant during gasification.
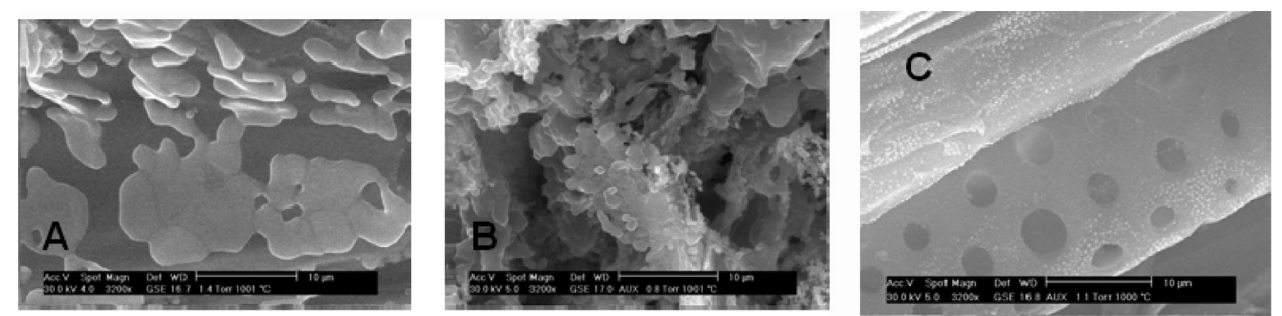

Figure 2. Char from gasification in an ESEM. Samples were heated to $1000{ }^{\circ} \mathrm{C}$ at $20 \mathrm{~K} \mathrm{~min}^{-1}$ under (A) steam, (B) air, and (C) $\mathrm{CO}_{2}$. Images shown are all at $1000^{\circ} \mathrm{C}$. Sintering is observed in A and B but not in C. (Reprinted with permission from ref 4. Copyright 2011 ASME Materials and Energy Recovery Division.)

experiment was to understand how the structure of the biomass changed as it was gasified, since surface area and pore size distribution are important properties of a catalyst. The impact of each of the different coreactants was studied, with an awareness of the possibility of sintering, which is known to happen with some catalysts at high temperatures. Sintering of the char should be avoided in order to maintain a high surface area char for catalytic applications. These experiments were done by exposing each sample to the same reaction conditions (temperature and time) with different coreactants. This means that the conversion was different in each case (due to different reaction kinetics), but the same reaction conditions allowed for a direct comparison of the surface structure for each of the coreactants. During $\mathrm{CO}_{2}$ gasification, the small pores in the biomass expanded and sintering was not observed at any point during the process. When air was used as a coreactant, reactions proceeded rapidly starting at low temperatures and sintering was observed at high temperatures, as shown in Figure 2. Steam gasification showed no significant changes in the structure at low temperatures, but at high temperatures $\left(1000{ }^{\circ} \mathrm{C}\right)$ the reaction proceeded rapidly and sintering was observed (Figure 2 ). When quantifying sintering, the specific surface area is one of the most reliable indicators of sintering. The kinetics of area reduction are linked to the mechanism of the sintering, and surface area is easily and reliably measured. Sintering causes both the specific surface area and the porosity to decrease and 
the density to increase. Sintering occurs in three stages. In the initial stage, the areas of contact between adjacent particles form and grow. In the intermediate stage, growing necks merge and the large number of small particles are replaced by a smaller number of large particles. This stage produces interparticle porosity, whose surface may be inaccessible both to reactant gas during the reaction and to the nitrogen used to measure the specific surface area. In the final stage of sintering, the pore spaces become broken up with isolated closed pores remaining, which shrink in size as densification proceeds. ${ }^{26-29}$ The absence of micropores in the char made under steam in the fluidized bed reactor was attributed to either a lack of micropore formation or the sintering of the micropores. While the pores that we can physically observe in the ESEM are on a micrometer scale (rather than a nanoscale), we can attempt to use the observed sintering behavior to explain the porosity measurements. In the ESEM, sintering is only observed at $1000{ }^{\circ} \mathrm{C}$. Since the fluidized bed experiments were conducted at $750{ }^{\circ} \mathrm{C}$, it is likely that during gasification, micropores were not formed since temperatures are too low for sintering. The density and surface area of char samples produced in the fluidized bed also suggests that sintering takes place at $1000{ }^{\circ} \mathrm{C}$. The density of char samples that were made under steam at 550 and $750{ }^{\circ} \mathrm{C}$ (for $30 \mathrm{~min}$ ) were 1.42 and $1.46 \mathrm{~g} \mathrm{~cm}^{-3}$, respectively. However, char that was made under steam at $1000{ }^{\circ} \mathrm{C}$ (not reported in Table 1) had a density of $1.76 \mathrm{~g} \mathrm{~cm}^{-3}$, and its surface area was $435 \mathrm{~m}^{2} \mathrm{~g}^{-1}$. Therefore, char produced under steam in a fluidized bed reactor at 1000 ${ }^{\circ} \mathrm{C}$ had a higher density and lower surface area than char produced at lower temperatures, suggesting that sintering of the char had taken place. Reactions with $\mathrm{CO}_{2}$ proceed more slowly than with steam or air, which may influence the porosity of the char. With slower reaction kinetics, the $\mathrm{CO}_{2}$ can diffuse into the pores of the biomass and modify the pore structure whereas the rapid decomposition under steam $\left(\right.$ at $1000^{\circ} \mathrm{C}$ ) or with air leads to a collapse in the pore structure of the char. These results show that the coreactant used for gasification is important in preventing sintering to maintain high surface area char.

3.2. Catalytic Activity of Char. The catalytic activity of the gasification char was tested by using it to catalyze the decomposition of light hydrocarbons $\left(\mathrm{CH}_{4}\right.$ and $\left.\mathrm{C}_{3} \mathrm{H}_{8}\right)$. These experiments were done in a TGA where a char sample was placed in the instrument and a hydrocarbon gas was passed over the sample as the temperature was increased. Mass gain represented carbon formation on the char surface from hydrocarbon decomposition. The results from tests with propane, methane, and nitrogen (to show thermal effects) are shown in Figure 3 for sample $\mathrm{H}_{2} \mathrm{O}-550-30$. Under nitrogen, some mass loss is observed, indicating that thermal treatment of the char results in some decomposition of the char. This is expected, especially when the char is heated above the temperature at which it was created $\left(550{ }^{\circ} \mathrm{C}\right)$. Additionally, volatiles are probably present in the char, since it was created below the temperature where tars can thermally decompose. Water loss also takes place, since the char was stored at atmospheric conditions that can lead to adsorption of water in the pores. In the presence of methane, mass gain is observed starting at $700{ }^{\circ} \mathrm{C}$, which represents the formation of solid carbon on the surface of the char, according to eq 1. Propane shows a higher mass gain. These results demonstrate the ability of char to catalyze the decomposition of hydrocarbons via the cleavage of $\mathrm{C}-\mathrm{C}$ and $\mathrm{C}-\mathrm{H}$ bonds. The $\mathrm{C}-\mathrm{H}$ bond in methane is one of the strongest aliphatic bonds, with a bond dissociation

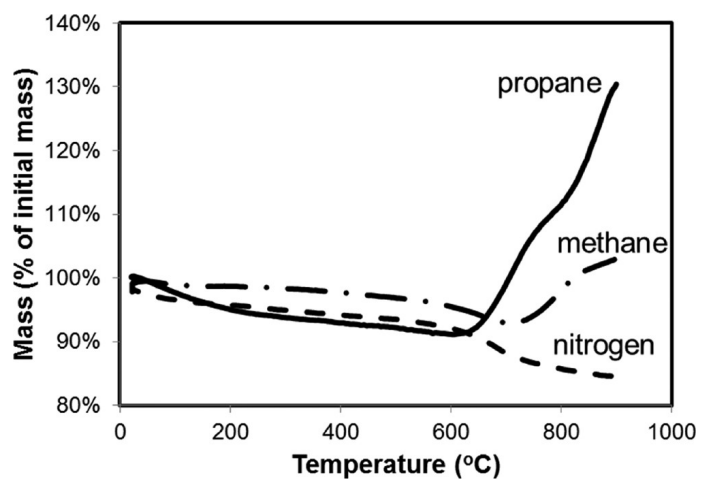

Figure 3. Mass gain of char during catalytic decomposition of hydrocarbons. Mass gain represents carbon deposition from cracking reactions, demonstrating the catalytic performance of the char.

energy of $439 \mathrm{~kJ} \mathrm{~mol}^{-1} .^{30}$ Toluene, which is a major component of tar, has a bond dissociation energy of $374 \mathrm{~kJ} / \mathrm{mol}$ for the cleavage of $\mathrm{H}$ from the methyl group and 426.8 for cleavage of the methyl group from the carbon ring, both of which are lower than the bond dissociation energy for methane. ${ }^{30}$ Char's ability to catalyze the decomposition of the hydrocarbons tested here suggests that it may also be a good catalyst for tar decomposition.

$$
\mathrm{CH}_{4} \rightarrow \mathrm{C}+2 \mathrm{H}_{2}
$$

Post-test characterization of the char was done in the ESEM/ EDX in order to understand its structural and chemical properties. Metals appear as bright spots in the ESEM images and compounds such as iron and calcium were detected in the char. An example of this is shown in Figure 4, where an iron

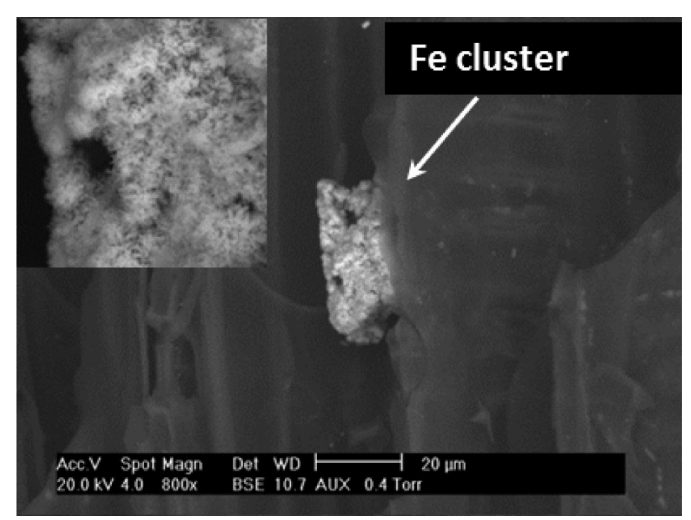

Figure 4. Iron cluster on the surface of the char that was generated at $550{ }^{\circ} \mathrm{C}$ under steam (sample $\mathrm{H}_{2} \mathrm{O}-550-30$ ). This shows the presence of catalytic metals on the surface of gasification char.

cluster (measured with EDX) was observed on the surface of the char. Some metals were present in clusters, while others were more evenly dispersed. Iron was present in few locations on the surface, with local concentrations ranging from 2 to 21 at. \%, whereas potassium was measured in almost all locations with concentrations typically $<1$ at. $\%$. Calcium was generally present in low concentrations $(<1$ at. \%) throughout the char but clusters of $\mathrm{Ca}$ were also observed. Girods et al. observed similar properties in char from wood particleboard waste. ${ }^{31}$ They found that $\mathrm{Na}, \mathrm{K}, \mathrm{Mg}$, and $\mathrm{Mn}$ were distributed throughout the sample, whereas $\mathrm{Ca}$ and $\mathrm{Fe}$ were localized. 

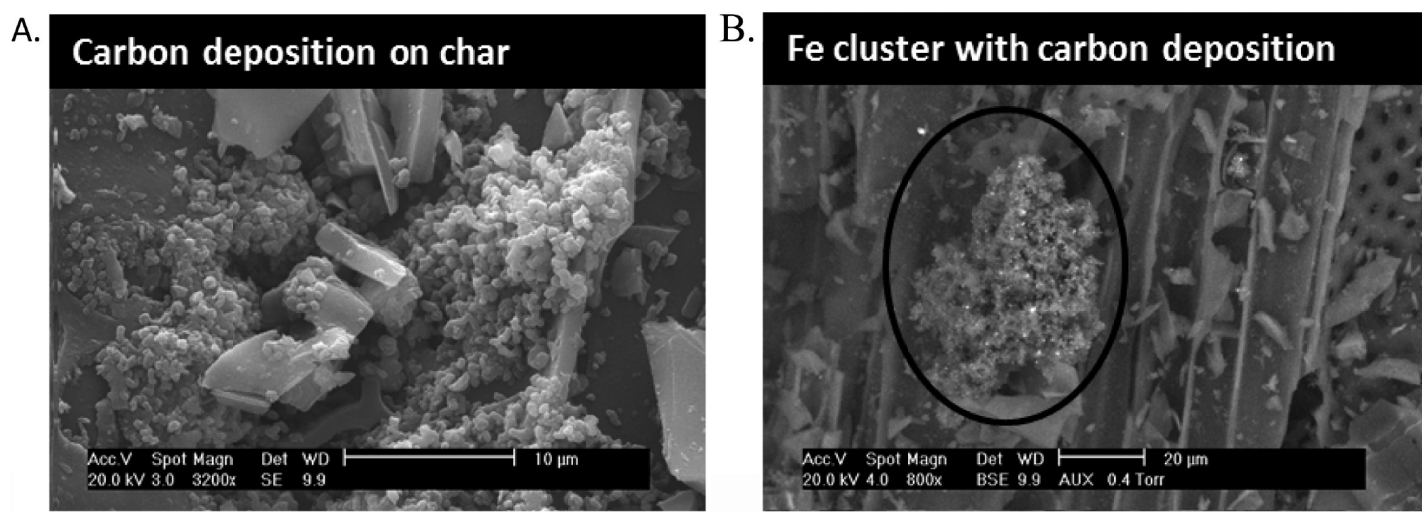

Figure 5. Char sample $\mathrm{H}_{2} \mathrm{O}-550-30$ after being used to catalyze propane decomposition. (A) Carbon deposition on char from catalytic decomposition of propane. (B) Iron cluster with carbon deposition, showing that iron is potentially a catalytic site.
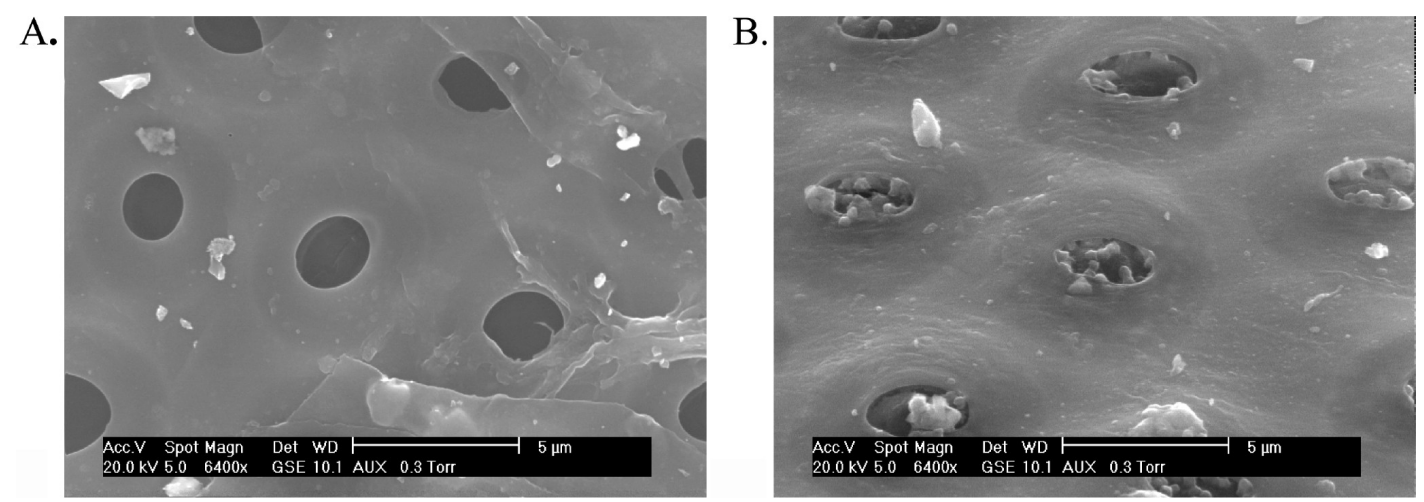

Figure 6. Char from $\mathrm{CO}_{2}$ gasification (sample $\mathrm{CO}_{2}-750-30$ ). (A) Char. (B) Char after being used to catalyze $\mathrm{CH}_{4}$ decomposition; carbon deposition is observed on the pores of the char.

The distribution of metals is important in catalytic applications, since metals or metal-carbon complexes are likely to be catalytic sites. During propane decomposition reactions, carbon was deposited both on the metals and on the carbon surface (Figure 5). Carbon deposition was easily observed as small clusters of carbon on an otherwise smooth char surface (Figure 5A). Measuring carbon deposition on iron clusters was not straightforward, since the iron is not smooth and is on a carbon support, therefore the EDX measured the deposition of carbon on carbon-iron complexes. It was important to distinguish if the carbon measured by the EDX was deposited from hydrocarbon cracking or the carbon of the char. The $\mathrm{C} / \mathrm{O}$ ratio was used as an indicator. The char contains approximately 91\% carbon (measured via char combustion with continuous $\mathrm{CO}_{2}$ measurements), which results in a $\mathrm{C} / \mathrm{O}$ ratio around 9.1, with the value changing locally. EDX measurements typically produced a $\mathrm{C} / \mathrm{O}$ ratio ranging from 5 to 15 . At the location of the iron cluster, the $\mathrm{C} / \mathrm{O}$ ratio was 100 , which is much higher than that of the char, and is likely a result of carbon deposition from propane cracking. Another possible explanation for this high carbon concentration is that the char itself has lower oxygen concentrations at the iron sites. However, EDX measurements of pretest char showed the $\mathrm{C} / \mathrm{O}$ ratio to be the same at the iron sites as elsewhere in the char. Therefore, the high carbon concentration at the iron in the post-test char is due to carbon deposition. This suggests that during thermal treatment of poplar wood, the iron in the wood migrates to the surface in clusters, which then acts as an active site for catalytic reactions. The redox properties of the metal-carbon complexes may be important for the catalytic properties of the char. The ability of the carbon to reduce the metal enables the formation of a metal in a reduced state, which is more catalytically active for some reactions. For example, Illán-Gómez et al. used char supported metal catalysts for $\mathrm{NO}_{x}$ reduction and studied the redox properties of the different complexes. They found the activity to be related to the ability of the metal to be oxidized by $\mathrm{NO}$ and reduced by carbon. ${ }^{12} \mathrm{Hsu}$ et al. also used carbon to catalyze the reduction of $\mathrm{NO}$ (with $\mathrm{NH}_{3}$ ) and found very low activity with metal-free carbon, but when impregnated with iron or copper, they achieved high conversions. ${ }^{10}$ Similarly, they attribute the activity to the redox properties of the carbonmetal complexes, where the metal was oxidized by $\mathrm{NO}$ and then reduced by carbon.

During catalytic decomposition of methane with char, carbon deposition was observed around the pores of the char, as shown in Figure 6. Figure 6A shows char which had not been used as a catalyst, and Figure 6B is an image of the char after catalyzing methane decomposition. Carbon deposition is observed around the pores of the char, and some pores are almost completely blocked. This shows that the porosity plays a role in the overall activity of the char. It is likely that activity will decrease as the pores become blocked, and the rate at which they are blocked is related to the pore size and distribution.

3.3. Impacts of Char Properties on Activity. Section 3.1 discussed how gasification conditions impact char properties. This section addresses how these properties impact the char's 
catalytic activity. Char samples were heated in a TGA to 900 at $5{ }^{\circ} \mathrm{C} \mathrm{min}{ }^{-1}$ under $30 \% \mathrm{CH}_{4}$ in $\mathrm{N}_{2}$. The reaction taking place was the decomposition of methane to carbon and $\mathrm{H}_{2}$, as shown in eq 1 . Activated carbon catalysts have been used to catalyze this reaction, and the performance has been attributed to the textural properties and surface functionalities. ${ }^{5}$ In the experiments reported here, the activity of the char was compared to a commercial precious metal catalyst to understand if the activity is in a practical range. In addition, we compared the activity of the char to $\gamma$-alumina, which is often used as a catalyst carrier. The BET surface area of each material tested is shown in Table 2. Mass gain with the different materials is shown in Figure 7.

Table 2. Materials Tested for Catalytic Decomposition of Methane

\begin{tabular}{lc}
\multicolumn{1}{c}{ catalyst } & surface area $\left(\mathrm{m}^{2} \mathrm{~g}^{-1}\right)$ \\
alumina catalyst carrier: $\gamma-\mathrm{Al}_{2} \mathrm{O}_{3}$ & 101 \\
commercial catalyst: $0.5 \% \mathrm{Pt}$ on $\gamma-\mathrm{Al}_{2} \mathrm{O}_{3}$ & 130 \\
char sample $\mathrm{H}_{2} \mathrm{O}-750-30$ & 429 \\
char sample $\mathrm{H}_{2} \mathrm{O}-750-60$ & 621 \\
char sample $\mathrm{CO}_{2}-750-30$ & 435 \\
char sample $\mathrm{CO}_{2}-920-30$ & 687 \\
\hline
\end{tabular}
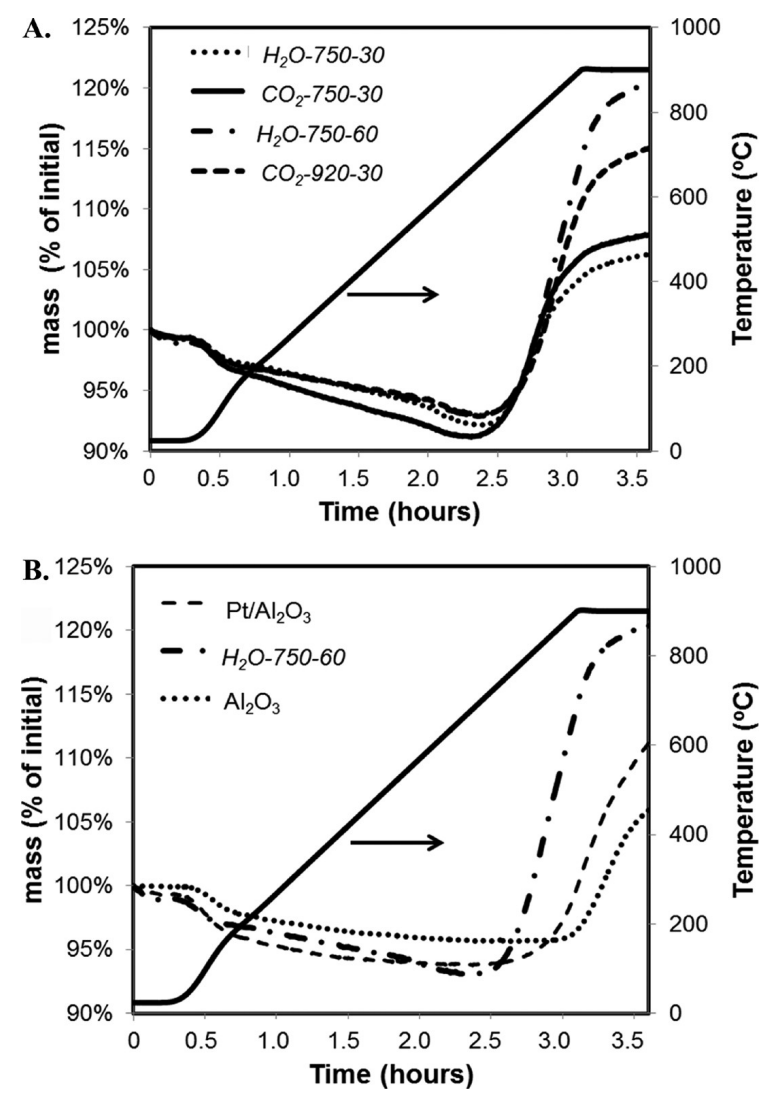

Figure 7. Mass gain in TGA of different materials when exposed to $\mathrm{CH}_{4}$ at high temperatures. Mass gain represents carbon deposition from catalytic cracking of $\mathrm{CH}_{4}$.

$\mathrm{H}_{2}$ was produced in each experiment and measured with a gas chromatograph. An example of the hydrogen production from a representative experiment is shown in Figure 8. The $\mathrm{H}_{2}$ production starts at the same time as the mass gain which confirms the relation of mass gain to $\mathrm{CH}_{4}$ cracking. For a given

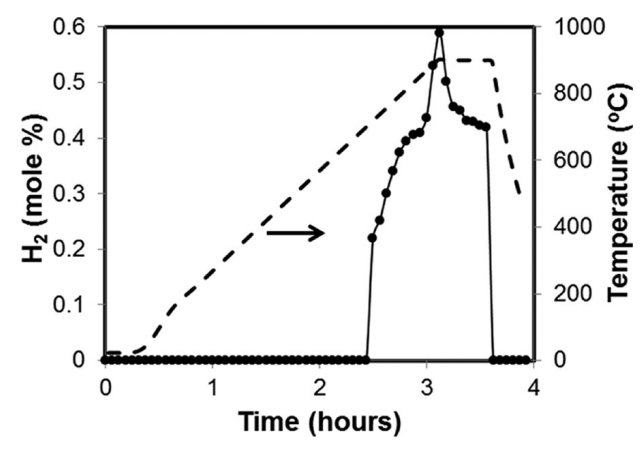

Figure 8. $\mathrm{H}_{2}$ produced during catalytic cracking of $\mathrm{CH}_{4}$ char sample $\mathrm{H}_{2} \mathrm{O}-750-60 \cdot \mathrm{H}_{2}$ production confirms the reaction is taking place according to eq $1\left(\mathrm{CH}_{4} \rightarrow \mathrm{C}+\mathrm{H}_{2}\right)$.

char type (char created in either $\mathrm{H}_{2} \mathrm{O}$ or $\mathrm{CO}_{2}$ ), higher surface area resulted in higher mass gain, indicating that increased surface area results in more catalytic activity. However, the activity of the char is not directly related to BET surface area. Dufour et al. showed that the pore size of wood char impacts its catalytic activity when used for methane decomposition. ${ }^{32}$ Specifically, they found that, with pore sizes $<1 \mathrm{~nm}$, diffusion limitations became significant and therefore activity was not directly proportional to BET surface area when pore size varied. This phenomenon was also observed in the experiments presented here. The mass gain for sample $\mathrm{CO}_{2}-920-30$ is lower than that for $\mathrm{H}_{2} \mathrm{O}-750-60$, even though the surface area of the former is higher. However, a comparison of samples made with $\mathrm{CO}_{2}$ and steam at 750 showed that char made with $\mathrm{CO}_{2}$ contained micropores whereas char made with steam did not. So, the lower performance of sample $\mathrm{CO}_{2}-920-30$ may be due to diffusion limitations in the micropores of the char.

The mass gain for each char sample starts between 2.3 and $2.4 \mathrm{~h}$, when the temperature is between 675 and $700{ }^{\circ} \mathrm{C}$. Mass gain for the Pt catalyst starts at $2.7 \mathrm{~h}$ when the temperature is $775{ }^{\circ} \mathrm{C}$, and for alumina, mass gain starts at $3.0 \mathrm{~h}$ when the temperature is $850{ }^{\circ} \mathrm{C}$. Therefore, the onset of reaction is at a lower temperature for char samples, which presents an advantage. Toward the end of the experiment, the slope of the mass gain curve decreases for char samples, indicating saturation of catalytic sites, or pore blocking. The $\mathrm{Pt}$ and $\mathrm{Al}_{2} \mathrm{O}_{3}$ do not demonstrate this, which may be because the reaction starts later, so saturation or pore blockage has not yet been reached. The pore volume could be used as an indicator to understand if the reaction rate decreases due to the pores becoming "filled". However, it is unclear whether carbon deposits in the micropores as well as the mesopores. In addition, carbon deposition has been observed on the surface of the char, so the pore volume cannot be used directly as an indicator of char activity. When using char as a catalyst, its longterm activity should be considered, and the process designed accordingly.

3.4. Stability of Char. Ideally, a catalyst should remain unchanged over time. However, this is rarely the case, as catalysts often deactivate (i.e., by deposition of carbon or poisons on the surface) or change morphology (i.e., via sintering) and oxidation state during a reaction. ${ }^{16}$ This is especially relevant when using char as a catalyst, since residual carbon on char can volatilize at temperatures as low as $300{ }^{\circ} \mathrm{C}$, whereas precious metals require temperatures that are well above $1000{ }^{\circ} \mathrm{C}$ to volatilize. Therefore, it is possible that catalysts made from char will react, resulting in a loss of catalyst 


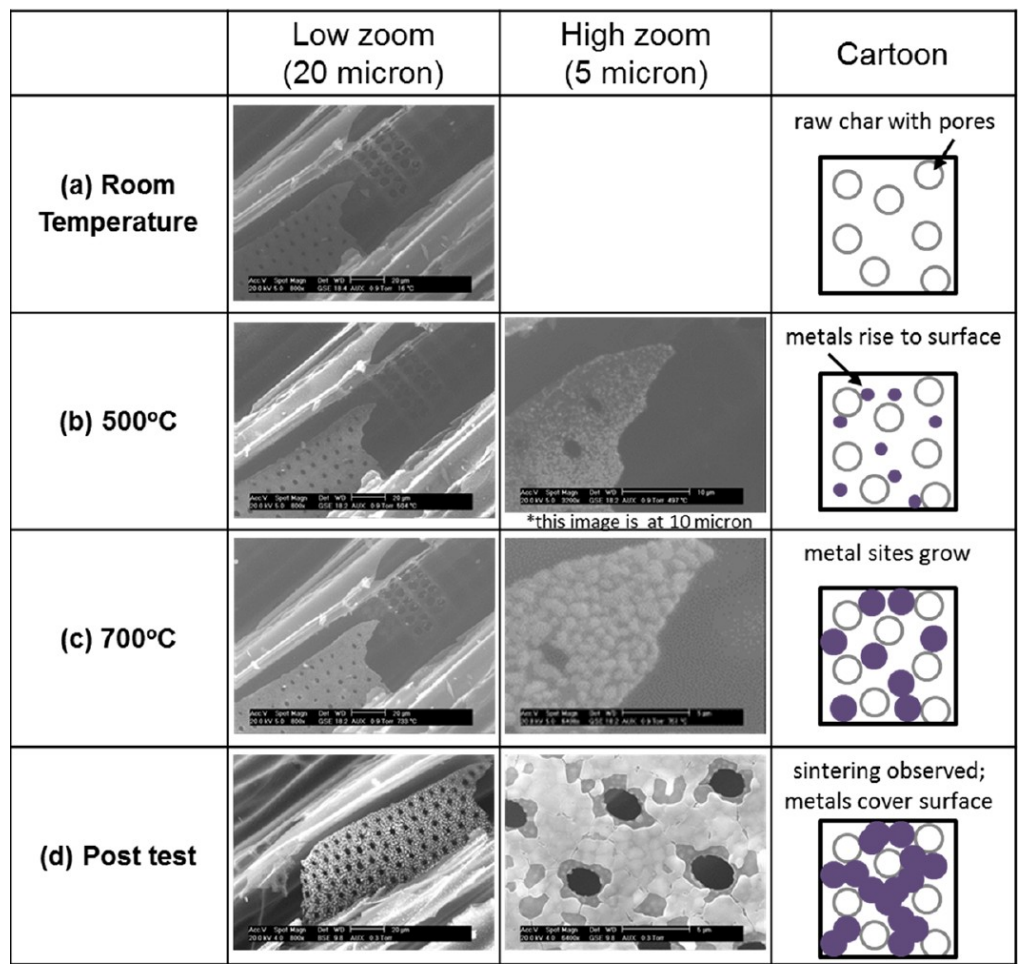

Figure 9. Char sample $\mathrm{H}_{2} \mathrm{O}-750-30$ during heating in an ESEM under $\mathrm{N}_{2}$. As temperature increases, minerals and oxygen, which appear as bright spots on the dark carbon surface, migrate to the surface of the char. At $1000{ }^{\circ} \mathrm{C}$, metals clusters have agglomerated.

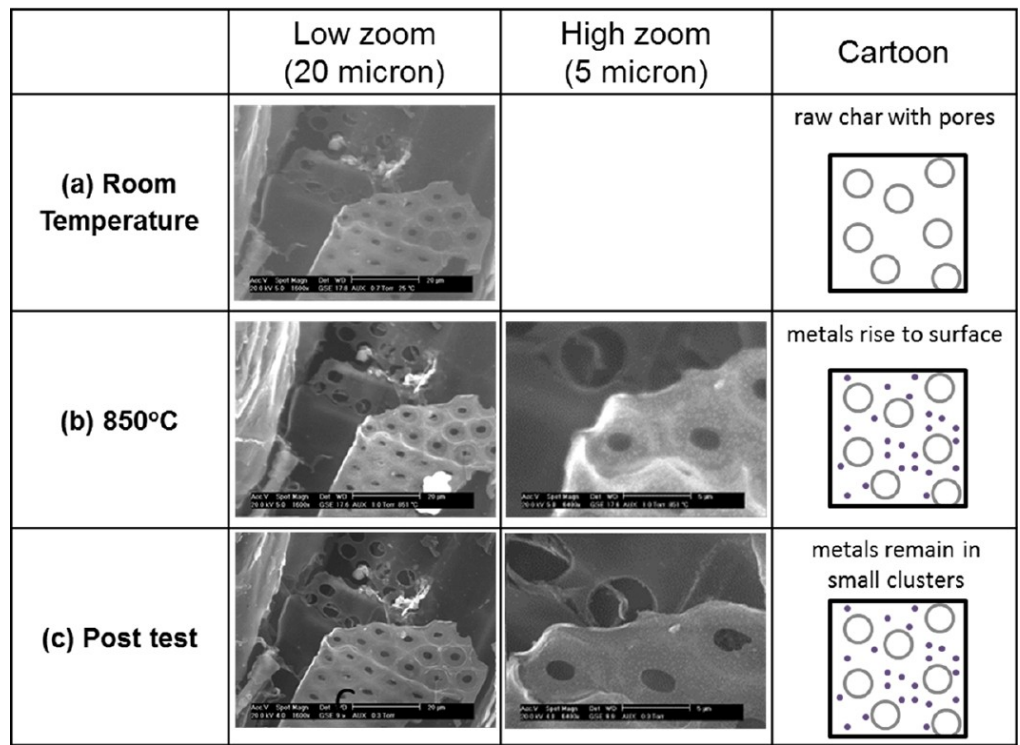

Figure 10. Char sample $\mathrm{CO}_{2}-750-30$ during heating in an ESEM under $\mathrm{N}_{2}$. As char is heated, oxygen and metals migrate to the surface and remain in isolated clusters.

material. Char from fluidized bed experiments was thermally treated in order to understand its stability at high temperatures. The stability of char was tested in two ways: by observing its physical changes while heating in an ESEM and by measuring its mass loss while heating it in a TGA. These experiments were done under nitrogen to observe thermal modifications only. While ultimately the char would be in an environment where it could react with tars, $\mathrm{CO}_{2}, \mathrm{H}_{2} \mathrm{O}$, etc., it was important to understand thermal modifications in order to distinguish this from reactions with coreactants. ESEM experiments were done for samples $\mathrm{CO}_{2}-750-30$ and $\mathrm{H}_{2} \mathrm{O}-750-30$. The surface area was very similar for both chars, but the yields were different (see section 3.1). The samples were heated under $\mathrm{N}_{2}$ at $20{ }^{\circ} \mathrm{C} \mathrm{min}^{-1}$ up to $1000{ }^{\circ} \mathrm{C}$. At low temperatures, no changes were observed in the structure of the char. Changes were first observed in sample $\mathrm{H}_{2} \mathrm{O}-750-30$ around $400{ }^{\circ} \mathrm{C}$. Small white spots appeared on the surface, which eventually became larger, as shown in Figure 9. These spots were later measured by EDX to 
be areas with higher concentrations of oxygen and metals. This suggests that the thermal treatment causes oxygen and metals to migrate to the surface of the char. The amount of metals at the surface increased as temperature rose, and eventually sintering was observed, creating what appeared to be a continuous layer over the char surface, as shown in Figure 9. The agglomeration of metals on char surfaces has also been observed and reported in literature. ${ }^{33}$ Kemiha et al. pyrolyzed wood waste that had been treated with CCA preservatives (chromated copper arsenate) and observed that the CCA metals initially vaporized and concentrated at the residue surface by condensation and nucleation, growth and agglomeration. ${ }^{34}$ Sample $\mathrm{CO}_{2}-750-30$ did not show any physical changes until around $850{ }^{\circ} \mathrm{C}$. With this char, metals and oxygen were observed in tiny clusters on the surface, as shown in Figure 10. As it was heated, the clusters remained small and isolated and sintering was not observed. In both cases, no significant changes were observed in the structure, but rather a migration or rearrangement of elements was observed.

The stability of the char at high temperatures was also tested in a TGA with $\mathrm{N}_{2}$. Three samples were tested: $\mathrm{CO}_{2}-750-30$, $\mathrm{H}_{2} \mathrm{O}-750-30$, and $\mathrm{CO}_{2}-920-30$. At low temperatures $\left(<150{ }^{\circ} \mathrm{C}\right)$, mass loss was due to water loss and was significantly different for all three samples, as shown in Figure 11. Since char is a

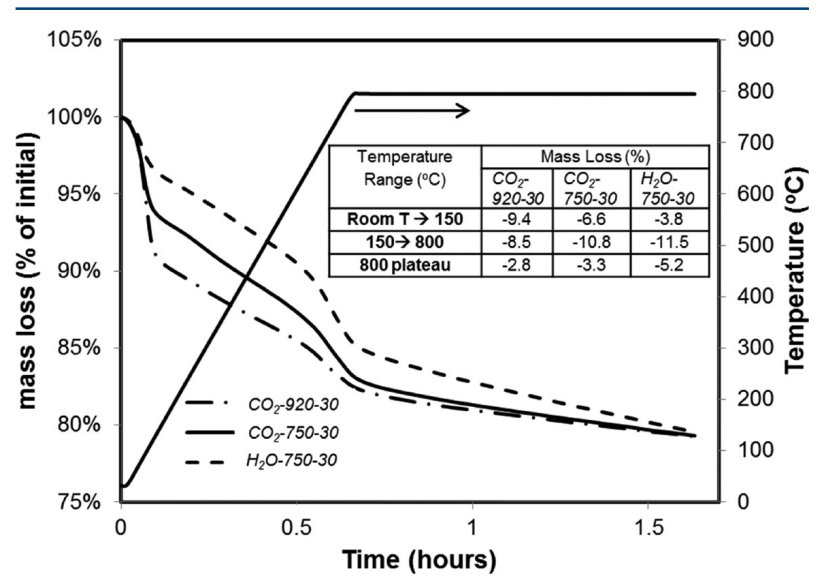

Figure 11. Mass loss of char samples $\mathrm{CO}_{2}-750-30, \mathrm{H}_{2} \mathrm{O}-750-30$, and $\mathrm{CO}_{2}-920-30$ when heated under nitrogen in a TGA. When using char as a catalyst, high temperature decomposition, shown here, should be considered.

porous material, water is absorbed in the pores. Char that was made at $920{ }^{\circ} \mathrm{C}$ in $\mathrm{CO}_{2}$ had a higher surface area than the char made at $750{ }^{\circ} \mathrm{C}$ in the same reaction environment (see section 3.1). Therefore, a higher surface area material has more pore volume and hence more water absorption. The two samples that were made at $750{ }^{\circ} \mathrm{C}$ (under $\mathrm{CO}_{2}$ and steam) had the same surface area, yet sample $\mathrm{CO}_{2}-750-30$ absorbed more water. This char had more micropores than $\mathrm{H}_{2} \mathrm{O}-750-30$ (see section 3.1), and these micropores have a better ability to retain water. Additionally, surface properties of the char may impact the amount of water adsorbed and energy required to remove it. Franz et al. studied adsorption of dissolved aromatics on activated carbon and found that surface oxygen attracts water molecules. ${ }^{25}$ Therefore, the presence of more water on the surface of the $\mathrm{CO}_{2}$ char may be indicative of higher surface oxygen concentrations. In the mid-temperature range (150$800^{\circ} \mathrm{C}$ ) the mass loss was similar for the two samples that were made at $750{ }^{\circ} \mathrm{C}$ and lower for the sample that was made at 920 ${ }^{\circ} \mathrm{C}$. Since the sample made at $920{ }^{\circ} \mathrm{C}$ was already exposed to higher temperatures, this is expected. That is, heating to $800{ }^{\circ} \mathrm{C}$ would not induce significant mass loss whereas samples that had only been exposed to $750{ }^{\circ} \mathrm{C}$ would decompose further as they were exposed to $800{ }^{\circ} \mathrm{C}$. At high temperatures, additional mass loss was observed, which may be a loss of volatiles that were still present in the char, or decomposition of the carbonoxygen matrix of the char to form $\mathrm{CO}$ or $\mathrm{CO}_{2}$. Therefore, by thermally treating the char, more carbon is released from it and is converted into gas phase products. If the char is used to catalyze decomposition of tars, the simultaneous decomposition of the char with decomposition of the tar results in higher overall gas recovery.

\section{CONCLUSIONS}

This paper presents the catalytic properties of char from gasification of poplar wood, for its use as a catalyst for tar decomposition. The use of char, which is a byproduct of gasification, offsets the need for commercial metal catalysts or high temperature thermal treatments to remove tars. The physical and chemical properties of biomass chars have been studied, and its catalytic performance for hydrocarbon cracking reactions has been tested. Analyzing chars that were created under different reaction environments demonstrated that the surface area of char could be modified by changing gasification conditions; increasing time or temperature increased the surface area of the char. However, at very high temperatures, or in the presence of certain coreactants, sintering occurred that reduced the overall char surface area. Sintering was observed during gasification with steam or air but not with $\mathrm{CO}_{2}$. The catalytic activity of chars generated under steam and $\mathrm{CO}_{2}$ was tested, and data suggests that both surface area and pore size must be considered when generating a highly active char. Higher surface area increases catalytic activity, but the presence of micropores can lead to diffusion limitations, which ultimately decreases reaction rates. Furthermore, analysis of the post-test chars showed carbon deposition on the pores of the char, which emphasizes the importance of the pores in the activity and durability of the char catalysts. The presence of metals such as iron in the char most likely play a role in the catalytic activity, but further research needs to be done to confirm this. When exposed to high temperatures, decomposition of the chars was observed, which suggests that when it is used for tar reforming additional carbon may be released into the product stream. Future work will include testing the catalytic performance of the chars for decomposition of toluene, which is a major component of gasification tar. In addition, the chemical properties of the char will be investigated in more detail in order to understand how the char properties should be modified in order to improve its catalytic performance.

\section{AUTHOR INFORMATION}

\section{Corresponding Author}

*E-mail: mc2352@columbia.edu.

Notes

The authors declare no competing financial interest.

\section{ACKNOWLEDGMENTS}

The authors would like to thank WTERT at Columbia University for supporting this research. The authors would also like to thank Christine Rolland (Ecole des Mines) for 
assistance with acquisition of ESEM images and insightful conversations.

\section{REFERENCES}

(1) Fernandez-Pereira, C.; de la Casa, J. A.; Gomez-Barea, A.; Arroyo, F.; Leiva, C.; Luna, Y. Application of biomass gasification fly ash for brick manufacturing. Fuel 2011, 90, 220.

(2) Granovskii, M.; Gerspacher, R.; Pugsley, T.; Sanchez, F. An effect of tar model compound toluene treatment with high-temperature flames. Fuel 2012, 92, 369.

(3) Simone, M.; Barontini, F.; Nicolella, C.; Tognotti, L. Gasification of pelletized biomass in a pilot scale downdraft gasifier. Bioresour. Technol. 2012, 116, 403.

(4) Klinghoffer, N. B.; Castaldi, M. J.; Nzihou, A. Beneficial use of ash and char from biomass gasification. In 19th Annual North American Waste-to-Energy Conference (NAWTEC19); ASME Materials and Energy Recovery Division: Lancaster, PA, 2011; pp 13.

(5) Carbon Materials for Catalysis. Wiley: Hoboken, NJ, 2009.

(6) Muradov, N.; Smith, F.; T-Raissi, A. Catalytic activity of carbons for methane decomposition reaction. Catal. Today 2005, 102, 225.

(7) Serrano, D. P.; Botas, J. A.; Fierro, J. L. G.; Guil-Lopez, R; Pizarro, P.; Gomez, G. Hydrogen production by methane decomposition: Origin of the catalytic activity of carbon materials. Fuel 2010, $89,1241$.

(8) Fidalgo, B.; Angel Menendez, J. Carbon materials as catalysts for decomposition and $\mathrm{CO}(2)$ reforming of methane: A review. Chin. J. Catal. 2011, 32, 207.

(9) Ma, W. P.; Kugler, E. L.; Dadyburjor, D. B. Effect of properties of various activated-carbon supports and supported $\mathrm{Fe}-\mathrm{Mo}-\mathrm{Cu}-\mathrm{K}$ catalysts on metal precursor distribution, metal reduction, and Fischer-Tropsch synthesis. Energy Fuels 2010, 24, 4099.

(10) Hsu, L. Y.; Teng, H. S. Catalytic NO reduction with $\mathrm{NH}_{3}$ over carbons modified by acid oxidation and by metal impregnation and its kinetic studies. Appl. Catal., B 2001, 35, 21.

(11) Bermudez, J. M.; Arenillas, A.; Menendez, J. A. Syngas from $\mathrm{CO}_{2}$ reforming of coke oven gas: Synergetic effect of activated carbon/ $\mathrm{Ni}-\gamma-\mathrm{Al}_{2} \mathrm{O}_{3}$ catalyst. Int. J. Hydrogen Energy 2011, 36, 13361.

(12) Illan-Gomez, M. J.; Raymundo-Pinero, E.; Garcia-Garcia, A.; Linares-Solano, A.; de Lecea, C. S. M. Catalytic $\mathrm{NO}_{x}$ reduction by carbon supporting metals. Appl. Catal., B 1999, 20, 267.

(13) Corella, J.; Orio, A.; Aznar, P. Biomass gasification with air in fluidized bed: Reforming of the gas composition with commercial steam reforming catalysts. Ind. Eng. Chem. Res. 1998, 37, 4617.

(14) Abu El-Rub, Z.; Bramer, E. A.; Brem, G. Review of catalysts for tar elimination in biomass gasification processes. Ind. Eng. Chem. Res. 2004, 43, 6911.

(15) Anis, S.; Zainal, Z. A. Tar reduction in biomass producer gas via mechanical, catalytic and thermal methods: A review. Renewable Sustainable Energy Rev. 2011, 15, 2355.

(16) Yung, M. M.; Jablonski, W. S.; Magrini-Bair, K. A. Review of catalytic conditioning of biomass-derived syngas. Energy Fuels 2009, 23, 1874

(17) Pfeifer, C.; Hofbauer, H. Development of catalytic tar decomposition downstream from a dual fluidized bed biomass steam gasifier. Powder Technol. 2008, 180, 9.

(18) Furusawa, T.; Miura, Y.; Kori, Y.; Sato, M.; Suzuki, N. The cycle usage test of $\mathrm{Ni} / \mathrm{MgO}$ catalyst for the steam reforming of naphthalene/benzene as model tar compounds of biomass gasification. Catal. Commun. 2009, 10, 552.

(19) Tomishige, K.; Miyazawa, T.; Asadullah, M.; Ito, S.; Kunimori, $\mathrm{K}$. Catalyst performance in reforming of tar derived from biomass over noble metal catalysts. Green Chem. 2003, 5, 399.

(20) Ruoppolo, G.; Miccio, F.; Chirone, R. Fluidized bed cogasification of wood and coal adopting primary catalytic method for tar abatement. Energy Fuels 2010, 24, 2034.

(21) Chaiwat, W.; Hasegawa, I.; Mae, K. Alternative reforming methods of primary tar released from gas treatment of biomass at low temperature for development of pyrolysis/gasification process. Ind. Eng. Chem. Res. 2010, 49, 3577.
(22) El-Rub, Z. A.; Bramer, E. A.; Brem, G. Experimental comparison of biomass chars with other catalysts for tar reduction. Fuel 2008, 87, 2243.

(23) Wang, D.; Yuan, W. Q.; Ji, W. Char and char-supported nickel catalysts for secondary syngas cleanup and conditioning. Appl. Energy 2011, 88, 1656

(24) Min, Z. H.; Yimsiri, P.; Asadullah, M.; Zhang, S.; Li, C. Z. Catalytic reforming of tar during gasification. Part II. Char as a catalyst or as a catalyst support for tar reforming. Fuel 2011, 90, 2545.

(25) Franz, M.; Arafat, H. A.; Pinto, N. G. Effect of chemical surface heterogeneity on the adsorption mechanism of dissolved aromatics on activated carbon. Carbon 2000, 38, 1807.

(26) White, J. Sintering and Related Phenomena; Gordon \& Breach: New York, 1967.

(27) German, R. M. Surface-area reduction kinetics during intermediate stage sintering. J. Am. Ceram. Soc. 1978, 61, 272.

(28) German, R. M.; Munir, Z. A. Surface-area reduction during isothermal sintering. J. Am. Ceram. Soc. 1976, 59, 379.

(29) Nicholso, D. Variation of surface area during thermal decomposition of solids. Trans. Faraday Soc. 1965, 61, 990.

(30) CRC Handbook of Chemistry and Physics, 88th ed.; CRC Press: Boca Raton, FL, 2008.

(31) Girods, P.; Dufour, A.; Fierro, V.; Rogaume, Y.; Rogaume, C.; Zoulalian, A.; Celzard, A. Activated carbons prepared from wood particleboard wastes: Characterization and phenol adsorption capacities. J. Hazard. Mater. 2009, 166, 491.

(32) Dufour, A.; Celzard, A.; Ouartassi, B.; Broust, F.; Fierro, V.; Zoulaljan, A. Effect of micropores diffusion on kinetics of $\mathrm{CH}_{4}$ decomposition over a wood-derived carbon catalyst. Appl. Catal, A 2009, 360, 120.

(33) Helsen, L.; Hacala, A. Formation of metal agglomerates during carbonization of chromated copper arsenate (CCA) treated wood waste: Comparison between a lab scale and an industrial plant. J. Hazard. Mater. 2006, 137, 1438.

(34) Kemiha, M.; Nzihou, A.; Mateos, D. Agglomeration of metals during pyrolysis of chromated copper arsenate (CCA) treated wood waste. High Temp. Mater. Process. (London) 2008, 27, 361. 